\title{
Acaricidal and antibacterial toxicities of Valeriana officinalis oils obtained by steam distillation extraction
}

\author{
Seon-A Choi ${ }^{1} \cdot$ Hoi-Seon Lee ${ }^{1}$ \\ 수증기 증류 추출법에 의해 얻어진 미국산 길초근 정유의 살비효과 및 \\ 항균효과
}

최선아 ${ }^{1} \cdot$ 이회선 $^{1}$

Received: 3 December 2018 / Accepted: 7 December 2018 / Published Online: 31 March 2019

(C) The Korean Society for Applied Biological Chemistry 2019

\begin{abstract}
The chemical compositions of the essential oil of Valeriana officinalis roots obtained by steam distillation method were analyzed by GC-MS. The 16 constituents were identified in the $V$. officinalis oil, and the most abundant compounds were patchouli alcohol (18.69\%) and $\beta$-gurjunene (15.26\%). Acaricidal effects of the $V$. officinalis oil were evaluated against Tyrophagus putrescentiae, Haemaphysalis longicornis larva and H. longicornis nymph by contact bioassay. The $\mathrm{LD}_{50}$ values against $T$. putrescentiae, $H$. longicornis larva and $H$. longicornis nymph were 28.01, 178.26 and $207.98 \mu \mathrm{g} / \mathrm{cm}^{2}$, respectively. Agar disc diffusion bioassay showed the antibacterial activity of the $V$. officinalis oil against foodborne pathogens, especially $L$. monocytogenes. These results showed that the essential oil of $V$. officinalis roots derived from USA has a potential for development as acaricide and antimicrobial.
\end{abstract}

Keywords Foodborne bacteria - Haemaphysalis longicornis . Tyrophagus putrescentiae $\cdot$ Valeriana officinalis

Hoi-Seon Lee $(\triangle)$

E-mail: hoiseon@jbnu.ac.kr

${ }^{1}$ Department of Bioenvironmental Chemistry, Chonbuk National University, Jeonju 54896, Republic of Korea

This is an Open Access article distributed under the terms of the Creative Commons Attribution Non-Commercial License (http://creativecommons. org/licenses/by-nc/3.0/) which permits unrestricted non-commercial use, distribution, and reproduction in any medium, provided the original work is properly cited.

\section{서 론}

고도의 산업화로 인하여 사회가 더욱 발전함에 따라 인류의 삶 에 대한 질적 수준이 높아지고 있으나, 그로 인해 지구 온난화 가 가속화되면서 각종 해충 및 병원균이 전세계적으로 확산되 고 있는 추세이다[1]. 이들을 효과적으로 방제하기 위하여 합성 살충제 및 살균제가 개발되어 있으나, 생태계에 대한 잔류성[2] 및 해충에 대한 저항성 발현[3] 등 불필요한 부작용이 보고되 면서 이를 대체할 방제 전략으로서 식물체 유래 화합물에 대한 생리활성이 주목 받고 있다. 식물은 오랜 시간 진화를 거듭하 면서 외부 환경으로부터 스스로를 보호하기 위한 기작으로 다 양한 이차 대사산물을 생산하였으며, 식물은 고유한 성질과 독 특한 생리활성을 지니게 되었다[4]. 이러한 식물체의 이차 대사 산물 중에 생리활성에 영향을 미치는 물질은 대부분 휘발성이 강한 터페노이드 계열 물질로[5], 다양한 해충에 대하여 유인, 기피, 섭식 저해, 흥분 및 살충효과 등을 일으키며[6], 또한 각 종 병원성 세균 및 균류에 대하여 항균활성을 나타낸다[7]. 따 라서 식물에서 유래한 이차 대사산물의 각종 생리활성 및 이들 을 이용하려는 연구가 활발히 진행 중이다.

작은소피참진드기(Haemaphysalis longicornis)는 참진드기과 (Ixodidae)의 일종으로 주로 동아시아와 오스트레일리아에서 발 견되는 흡혈성 진드기이다[8]. 이는 대표적인 인수공통감염병 매 개 진드기로서 쯔쯔가무시증을 유발하는 리케차 및 중증열성혈 소판감소증후군(severe fever with thrombocytopenia syndrome, SFTS) 바이러스 등을 인간에게 전염시켜[8] 치명적인 피해를 일 으킨다. 특히 SFTS는 2012년에 우리나라에서 첫 감염 사례가 보고되었으며, 약 $30 \%$ 에 달하는 치사율을 보이고 있어서 큰 문 제가 되고 있다[9]. 저장식품진드기의 일종인 긴털가루응애 (Tyrophagus putrescentiae)는 저장중인 곡물에서 쉽게 발생하며, 
습도가 낮은 환경에서도 쉽게 견디고 최적 생육온도의 범위가 넓어 방제에 큰 어려움을 겪고 있는 해충이다[10]. 이들은 곡물 에만 한정하지 않고 고지방과 단백질을 함유한 햄, 치즈 및 견 과류 등에서도 발생하며[10], 저장식품 관련 종사자에 각종 질 병을 일으킨다[11]. 그러나 이들을 방제하기 위한 현존하는 합 성 살비제가 높은 잔류성으로 인하여 관련업계 종사자 및 소비 자들의 안전성에 대한 문제가 제기됨에 따라[12,13] 이를 대체 할 안전한 방제법 마련이 시급한 실정이다.

식품을 섭취하는 과정에서 다양한 병원균이 체내로 유입될 수 있는데, Bacillus, Listeria, Salmonella 및 Staphylococcus와 같은 균들은 식중독, 패혈증 등의 질병을 일으키며, 때로는 사 람을 죽음에 이르게 한다[14]. 식중독균은 일반적으로 가공육을 생산하는 과정에서 오염되며, 식재료의 잘못된 보관 및 취급으 로 인해 발생하기도 한다[14,15].

길초근(Valeriana officinalis)은 중국에서 약용식물로 쓰이는 마타리과(Valeriaceae)의 다년생 식물로 주로 뿌리를 이용한다. 길초근은 중추신경계를 안정시키는 기능이 있어 신경안정제 및 항경련제로 쓰이고 있으며[16,17], 수면을 유도하는 생리활성도 보고된 바 있다[18]. 그러나 이러한 생리활성이 밝혀져 있음에 도 불구하고, 길초근의 해충 및 미생물에 대한 살충활성 및 항 균활성에 대해서는 연구가 부족한 실정이다. 따라서 본 연구에 서는 길초근의 작은소피참진드기 및 긴털가루응애에 대한 살비 활성과 식중독균에 대한 항균활성을 알아보고자 하였다.

\section{재료 및 방법}

\section{정유 추출}

본 연구에 사용한 길초근 정유는 전라북도 전주에 소재한 한약 재 전문점에서 구입한 미국산 길초근을 수증기증류 추출법(steam distillation extraction)을 통해 추출하였다. 마쇄한 길초근 분말 $150 \mathrm{~g}$ 을 증류수 $1,500 \mathrm{~mL}$ 와 혼합하고, 이를 $100^{\circ} \mathrm{C}$ 로 가열하여 증기를 발생시켜 정유성분을 추출하였으며, 추출 용매로 헥산 $300 \mathrm{~mL}$ 를 사용하여 정유성분을 포집하였다. 4시간 후 정유성분 이 함유된 헥산 용매층을 수집하여 감압 농축을 통해 용매만을 휘발시킨 후 순수한 정유성분을 얻었으며, 수집된 정유성분은 $4{ }^{\circ} \mathrm{C}$ 에서 냉장 보관하였다.

\section{GC-MS 성분분석}

길초근 정유는 GC (Agilient HP-6890)-MS (Agilent 5973IV) (Santa Clara, CA, USA)를 통해 분석되었다. 컬럼은 DB-5 $(0.25 \mathrm{~mm} \times 30 \mathrm{~mL} \times 0.25 \mu)$ 를 이용하였고, Carrier gas는 헬륨 기 체(유량 $0.8 \mathrm{~mL} / \mathrm{min}$ )를 이용하였다. Ion source 및 주입구 온도 는 각각 $220{ }^{\circ} \mathrm{C}$ 및 $210^{\circ} \mathrm{C}$ 로 설정하였고, oven 온도는 $2{ }^{\circ} \mathrm{C} /$ $\mathrm{min}$ 의 속도로 $20^{\circ} \mathrm{C}$ 에서 $220^{\circ} \mathrm{C}$ 까지 증가시켜 15 분 동안 분석 을 수행하였다. 검출기는 $220^{\circ} \mathrm{C}$ 에서 $70 \mathrm{eV}$ 의 이온화 조건에서 수행하였다.

\section{공시충 채집 및 사육}

작은소피참진드기는 전라북도 전주시에 소재한 전주천 및 완주 군에 소재한 상관저수지의 인근에서 cloth dragging 기법을 통 해 채집하였다[19]. 그 과정은 지름 $6 \mathrm{~cm}$, 길이 $100 \mathrm{~cm}$ 의 $\mathrm{PVC}$
파이프에 $100 \times 150 \mathrm{~cm}$ 의 천을 붙인 후, 파이프 양 끝에 끈을 묶 어 수풀 위에 놓고 바닥을 끌어 채집하였다. 채집한 진드기는 $50 \mathrm{~mL}$ falcon tube에 담아 온도 $26 \pm 1{ }^{\circ} \mathrm{C}$ 와 상대습도 $80 \pm 3 \%$ 의 조건에서 보관하였으며, 작은소피참진드기의 동정은 Yamaguti 등[20]이 제시한 방법을 통해 수행하였다.

긴털가루응애는 전북대학교 농업생명과학대학 응용식물생화 학실험실의 곤충사육실에서 10 년 이상 살비제에 노출되지 않은 감수성 계통으로 사육한 것을 연구에 사용하였다. 먹이는 치어 사료와 건조효모를 $1: 1(\mathrm{w} / \mathrm{w})$ 의 비율로 섞은 후 $121{ }^{\circ} \mathrm{C}$ 에서 15 분동안 멸균하여 사용하였다. 사육은 $12.5 \times 12.5 \times 7.0 \mathrm{~cm}$ 의 플라 스틱 상자에 먹이와 진드기를 혼합하여 넣은 후, 포화염화나트 륨 수용액을 약 $0.6 \mathrm{~cm}$ 의 높이로 채운 $20.5 \times 20.5 \times 20.5 \mathrm{~cm}$ 크기 의 플라스틱상자에 넣어 온도 $27 \pm 1{ }^{\circ} \mathrm{C}$ 와 상대습도 $70 \pm 5 \%$ 의 빛 이 차단된 암조건에서 사육하였다.

\section{사용 균주}

항균활성 검정에 사용한 균주는 한국미생물보존센터(Korean Culture Center of Microorganisms, $\mathrm{KCCM}$ )에서 분양 받아 사 용하였으며, 그람양성균 Bacillus cereus (ATCC 14579), Listeria monocytogenes (ATCC 15313), Salmonella enterica (ATCC 43971), Salmonella typhimurium (IFO 14193) 및 Shigella sonnei (ATCC 25931)의 5종과 그람음성균 Staphylococcus aureus (ATCC 25923), Staphylococcus epidermidis (ATCC 12228) 및 Staphylococcus intermedius (ATCC 29663) 3종의 균주를 사용하였다.

\section{접촉독성 검정}

작은소피참진드기 유충 \&약충 및 긴털가루응애 성충에 대한 살 비활성 검정은 양 등[21]이 수행한 접촉독성법을 통해 수행되 었다. 길초근 정유는 메탄올에 적절한 농도로 희석시켜 지름 55 $\mathrm{mm}$ 의 filter paper에 $100 \mu \mathrm{L}$ 씩 처리하였다. 처리한 filter paper 는 10 분간 음건한 후 지름 $60 \mathrm{~mm}$ 의 petri dish 바닥에 놓고 그 위에 작은소피참진드기 유충 $\&$ 약충 및 긴털가루응애 성충을 각 각 20마리씩 접종하였다. 처리된 petri dish는 para film으로 밀 봉하여 온도 $27 \pm 1{ }^{\circ} \mathrm{C}$, 상대습도 $70 \pm 5 \%$, 암조건의 incubator에 보관하였으며, 24 시간 이후에 살비효과를 확인하였다. 각 개체 에 대한 살비 여부는 침 끝으로 가볍게 자극을 주었을 때 미동 도 하지 않을 경우 죽은 것으로 판단하였다.

\section{항균활성 검정}

식중독균에 대한 항균활성 검정은 agar disc diffusion법을 통해 수행되었다. 각 균주는 시험 전 nutrient broth에 온도 $37^{\circ} \mathrm{C}$ 에 서 24 시간 동안 배양하여 준비하였다. 길초근 정유 $10 \mathrm{mg}$ 을 메 탄올 $100 \mu \mathrm{L}$ 에 희석한 후, 지름 $8 \mathrm{~mm}$ 의 paper disc에 주입하 여 10 분간 음건하였다. 그리고 $\mathrm{MHA}$ 평판배지에 균주액 100 $\mu \mathrm{L}$ 를 분주하여 도말한 후, 그 위에 처리한 paper disc를 점적하 였다. 처리된 배지는 온도 $37^{\circ} \mathrm{C}$ 의 incubator에 보관하였으며, 24 시간 이후에 생육저해환(inhibition zone)의 크기를 측정하여 항균활성을 검정하였다.

\section{통계분석}

작은소피참진드기 및 긴털가루응애에 대한 살비활성 결과는 
SPSS ver.12.0 프로그램을 통해 Probit 분석을 실시하였으며, 이 를 통해 반수치사량 $\left(\mathrm{LD}_{50}\right)$, slope 및 $\chi^{2}$ (chi-square value)을 계산하여 나타내었다.

\section{결과 및 고찰}

미국산 길초근의 수증기증류 추출법에 의해 추출된 정유의 구 성성분을 확인하기 위해 GC-MS 성분분석을 수행한 결과를 Table 1에 나타내었으며, 총 16 종의 구성성분이 검출되었다. 전 체 정유성분 중에 가장 많은 함량을 나타낸 성분은 juniper camphor로 $18.69 \%$ 를 차지하였으며, 그 다음으로는 $\beta$-gurjunene 이 $15.26 \%$ 를 차지하였다. 일반적으로 길초근 정유에는 bornyl acetate가 함유되어 있는 것으로 알려져 있는데[22-24] 본 연구 에서는 bornyl acetate가 검출되지 않았으며, monoterpene의 비 율이 $1.79 \%$ 로 다른 연구 결과에 비해 적은 함량을 나타내었다. 또한 본 연구에서 수행한 길초근은 원산지에 따라 구성성분 및 함량이 상이하게 나타났는데[22-24], 이러한 차이는 재배지의 기 후, 토양 상태 및 식물체의 유전적 차이에 의한 것으로 분석된 다[25].

수증기증류 추출법으로 추출한 미국산 길초근 정유의 작은소 피참진드기 유충 \&약충 및 긴털가루응애 성충에 대한 살비활성 을 확인한 결과를 Table 2에 나타내었다. 접촉법에 의한 긴털 가루응애 성충의 $\mathrm{LD}_{50}$ 값은 $28.01 \mu \mathrm{g} / \mathrm{cm}^{2}$ 으로 나타났으며, 작은 소피참진드기 유충 및 약충의 $\mathrm{LD}_{50}$ 값은 $178.26 \mu \mathrm{g} / \mathrm{cm}^{2}$ 및 $207.98 \mu \mathrm{g} / \mathrm{cm}^{2}$ 으로 나타났다. 본 결과를 통해 미국산 길초근 정 유가 긴털가루응애 성충, 작은소피참진드기 유충 $\&$ 약충에 대하 여 우수한 접촉독성을 나타내는 것을 확인하였으며, 작은소피참 진드기에 대해서는 유충이 약충보다 더 높은 감수성을 나타냄 을 확인하였다. 길초근 정유는 담배거세미나방의 일종인 Spodoptera littoralis 유충에 대하여 살충활성을 나타낸 바 있으 며[26], 또한 길초근과 같은 마타리과에 속한 Valeriana jatamansi 정유가 모기의 일종인 Aedes aegypti, Aedes albopictus, Anopheles culicifacies, Anopheles stephensi 및 Culex quinquefasciatus 유
Table 1 GC-MS analysis of essential oil of Valeriana officinalis roots cultivated from USA

\begin{tabular}{|c|c|c|c|}
\hline No & Compounds & $\mathrm{RT}^{\mathrm{a}}$ & Composition (\%) \\
\hline 1 & $\alpha$-Pinene & 4.970 & 1.79 \\
\hline 2 & 3-Methylvaleric acid & 5.098 & 4.34 \\
\hline 3 & $\beta$-Patchoulene & 12.759 & 3.21 \\
\hline 4 & $\alpha$-Santalene & 13.212 & 2.97 \\
\hline 5 & $\alpha$-Bergamotene & 13.410 & 1.50 \\
\hline 6 & $\beta$-Gurjunene & 13.489 & 15.26 \\
\hline 7 & Farnesol & 13.564 & 6.48 \\
\hline 8 & $\alpha$-Panasinsene & 13.683 & 5.84 \\
\hline 9 & $\alpha$-Gurjunene & 13.743 & 9.53 \\
\hline 10 & $\alpha$-Patchoulene & 13.864 & 3.21 \\
\hline 11 & $(+)$-Ledene & 14.330 & 1.73 \\
\hline 12 & $\beta$-Elemene & 14.368 & 1.72 \\
\hline 13 & D-Guaiene & 14.441 & 9.54 \\
\hline 14 & Exo-2-hydroxycineole & 14.797 & 1.15 \\
\hline 15 & Juniper camphor & 15.323 & 18.69 \\
\hline \multirow[t]{7}{*}{16} & Patchouli alcohol & 16.569 & 5.70 \\
\hline & Major Grouped Compour & & \\
\hline & Fatty acid & & 4.34 \\
\hline & Monoterpene hydrocarbon & & 1.79 \\
\hline & Sesquiterpene alcohol & & 30.87 \\
\hline & Sesquiterpene ether & & 1.15 \\
\hline & Sesquiterpene hydrocarbon & & 54.51 \\
\hline \multicolumn{2}{|c|}{ Total (\%) } & & 92.66 \\
\hline
\end{tabular}

${ }^{\text {aThe retention time }}$

충에 대하여 살충활성이 밝혀진 바 있다[27].

수증기증류 추출법으로 추출한 미국산 길초근 정유의 식중독 균 8 종에 대한 항균활성을 확인한 결과를 Table 3 에 나타내었 다. 미국산 길초근 정유는 본 연구에서 수행한 식중독균 8 종에 대하여 항균활성을 나타내었으며, 특히 그람양성균에 대하여 뛰 어난 살충활성을 나타내었다. 가장 우수한 항균활성을 나타낸

Table 2 Acaricidal activity of essential oil of Valeriana officinalis against Tyrophagus putrescentiae and Haemaphysalis longicornis

\begin{tabular}{cccccc}
\hline \hline Insects & Stage & $\mathrm{LD}_{50}\left(\mu \mathrm{g} / \mathrm{cm}^{2}\right)$ & $95 \% \mathrm{CI}$ & Slope $\pm \mathrm{SE}$ & $\chi^{2}(\mathrm{df}, p)$ \\
\hline T. putrescentiae & Adult & 28.01 & $13.51-47.62$ & $2.42 \pm 0.38$ & $7.351(4,0.118)$ \\
H. longicornis & Larva & 178.26 & $143.25-219.05$ & $3.39 \pm 0.52$ & $3.855(4,0.426)$ \\
& Nymph & 207.98 & $126.01-347.75$ & $3.19 \pm 0.52$ & $7.371(4,0.118)$ \\
\hline
\end{tabular}

Table 3 Antibacterial activity of essential oil of Valeriana officinalis roots against foodborne bacteria

\begin{tabular}{|c|c|c|c|c|c|c|c|c|}
\hline \multirow{3}{*}{ Test material } & \multicolumn{8}{|c|}{ Inhibition zone $\mathrm{a}^{\mathrm{a}}$} \\
\hline & \multicolumn{5}{|c|}{ Gram-positive bacteria ${ }^{b}$} & \multicolumn{3}{|c|}{ Gram-negative bacteria ${ }^{\mathrm{b}}$} \\
\hline & $\mathrm{Bc}$ & $\mathrm{Lm}$ & Sae & $\mathrm{St}$ & Ss & $\mathrm{Sa}$ & $\mathrm{Se}$ & $\mathrm{Si}$ \\
\hline V. officinalis oil & $++^{\mathrm{c}}$ & +++ & + & + & ++ & + & + & + \\
\hline Negative control & - & - & - & - & - & - & - & - \\
\hline
\end{tabular}

\footnotetext{
${ }^{\mathrm{a}} 10 \mathrm{mg}$ per disc
}

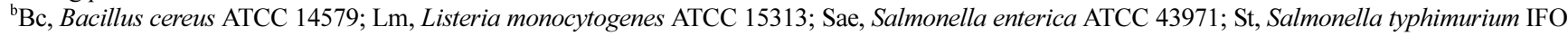
14193; Ss, Shigella sonnei ATCC 25931; Sa, Staphylococcus aureus ATCC 25923; Se, Staphylococcus epidermidis ATCC 12228; Si, Staphylococcus intermedius ATCC 29663

${ }^{\mathrm{c}}$ Diameter of inhibition zone $20 \mathrm{~mm},+++$; 16 to $20 \mathrm{~mm},++$; 11 to $15 \mathrm{~mm},+$; $10 \mathrm{~mm}$, - 
균주는 Listeria monocytogenes이며, 그 다음으로 Bacillus cereus 및 Shigella sonnei가 우수한 항균활성을 나타내었다. 그 리고 나머지 5종 균주(Salmonella enterica, Salmonella typhimurium, Staphylococcus aureus, Staphylococcus epidermidis 및 Staphylococcus intermedius)에 대해서는 상대적으로 낮은 항 균활성을 나타내었다. Wang 외[22]의 연구에 의하면 중국산 길 초근 정유가 S. typhimurium 및 $S$. aureus에 대하여 우수한 항 균활성을 보고한 바 있으며, 본 연구 결과와 상응하는 결과를 나타내었다. Jeong 등[28]의 연구에서는 Periploca sepium 정유 의 식중독균 6 종에 대한 항균활성을 검정하였는데, $L$. monocytogenes 및 S. sonnei에 대하여 본 연구와 비슷한 수준 의 항균활성을 나타내었다. 이를 통해 길초근 정유 또한 뛰어 난 항균활성을 나타내는 것을 확인할 수 있었다.

본 연구를 통해 수증기증류 추출에 의한 미국산 길초근 정유의 작은소피참진드기, 긴털가루응애 및 식중독균에 대한 살비활성 및 항균활성을 확인하였으며, 새로운 천연 살비제 및 항생제로 서의 잠재력이 있다고 판단하였다.

\section{초 록}

수증기증류 추출법에 의한 미국산 길초근(Valeriana officinalis) 의 구성성분을 알아보기 위해 GC-MS 분석을 수행한 결과, 주 요 성분이 patchouli alcohol (18.69\%) 및 $\beta$-gurjunene $(15.26 \%)$ 인 것으로 나타났다. 그리고 길초근 정유의 살비활성 및 항균 활성을 알아보기 위해 작은소피참진드기 및 긴털가루응애에 대 하여 접촉독성법을 실시하였고, 식중독균 8 종에 대하여 agar disc diffusion법을 실시하였다. 그 결과, 긴털가루응애 성충에 대 하여 $28.01 \mu \mathrm{g} / \mathrm{cm}^{2}$ 의 $\mathrm{LD}_{50}$ 값을 나타내었으며, 작은소피참진드기 유충 및 약충에 대하여 각각 178.26 및 $207.98 \mu \mathrm{g} / \mathrm{cm}^{2}$ 의 $\mathrm{LD}_{50}$ 값을 나타내었다. 또한 식중독균은 8종 균주에 대하여 항균활 성을 나타내었으며, 특히 L.monocytogenes에 대하여 우수한 항 균활성을 나타내었다. 따라서 본 연구를 통해 수증기증류 추출 법에 의한 길초근 정유가 살비제 및 항생제로서의 가치가 있음 을 확인하였다.

Keywords Foodborne bacteria · Haemaphysalis longicornis . Tyrophagus putrescentiae · Valeriana officinalis

감사의 글 본 연구과제는 방역연계 범부처 감염병 연구개발사업( $\mathrm{HG} 18 \mathrm{C} 0055)$ 의 지원으로 수행되었습니다.

\section{References}

1. McMichael AJ, Woodruff RE, Hales S (2006) Climate change and human health: present and future risks. Lancet 367: 859-869

2. Colborn T, Vom Saal FS, Soto AM (2000) Developmental effects of endocrine-disrupting chemicals in wildlife and humans. Environ Health Perspect 101: 378-384

3. Hemingway J, Ranson H (2000) Insecticide resistance in insect vectors of human disease. Annu Rev Entomol 45: 371-391

4. Akula R, Ravishankar GA (2011) Influence of abiotic stress signals on secondary metabolites in plants. Plant Signal Behav 6: 1720-1731
5. Figueiredo AC, Barroso JG, Pedro LG, Scheffer JJC (2008) Factors affecting secondary metabolite production in plants: volatile components and essential oils. Flavour Frag J 23: 213-226

6. Enan E (2001) Insecticidal activity of essential oils: octopaminergic sites of action. Comp Biochem Physiol C-Toxicol Pharmacol 130: 325-337

7. Wink M (1988) Plant breeding: importance of plant secondary metabolites for protection against pathogens and herbivores. Theor Appl Genet 75: 225-233

8. Boldbaatar D, Sikasunge CS, Battsetseg B, Xuan X, Fujisaki K (2006) Molecular cloning and functional characterization of an aspartic protease from the hard tick Haemaphysalis longicornis. Insect Biochemistry and Molecular Biology 36: 25-36

9. Kim KH, Yi JY, Kim GY, Choi SJ, Jun KI, Kim NH, Choe PG, Kim NJ, Lee JK, Oh MD (2013) Severe fever with thrombocytopenia syndrome, South Korea, 2012. Emerg Infect Dis 19: 1892-1894

10. Hughes AM (1976) The Mites of Stored Food and Houses. H. M. S. O., London

11. Heide S, Niemeijer NR, Hovenga H, Monchy JGR, Dubois AEJ, Kauffman HF (1998) Prevalence of sensitization to the storage mites Acarus siro, Tyrophagus putrescentiae, and Lepidoglyphus destructor in allergic patients with different degrees of sensitization to the housedust mite Dermatophagoides pteronyssinus. Allergy 53: 426-430

12. Collins DA (2006) A review of alternatives to organophosphorus compounds for the control of storage mites. J Stored Prod Res 42: 395426

13. Lee CH, Sung BK, Lee HS (2006) Acaricidal activity of fennel seed oils and their main components against Tyrophagus putrescentiae, a storedfood mite. J Stored Prod Res 42: 8-14

14. Newell DG, Koopmans M, Verhoef L, Duizer E, Aidara-Kane A, Sprong H, Opsteegh M, Langelaar M, Threfall J, Scheutz F, Giessen J, Kruse H (2010) Food-borne diseases - The challenges of 20 years ago still persist while new ones continue to emerge. Int J Food Microbiol 139: S3-S15

15. Chung JK, Lee JC, Ha DR (2014) Antimicrobial Activities of Sword Bean (Canavalia gladiata) Extracts against Food Poisoning Bacteria. J Food Hyg Saf 29: 376-382

16. Bos R, Hendriks H, Scheffer JJC, Woerdenbag HJ (1998) Cytotoxic potential of valerian constituents and valerian tinctures. Phytomedicine 5: 219-225

17. Leuschner J, Muller J, Rudmann M (1993) Characterisation of the central nervous depressant activity of a commercially available valerian root extract. Arzneimittelforschung 43: 638-641

18. Leathwood PD, Chauffard F, Heck E, Munoz-Box R (1982) Aqueous extract of valerian root (Valeriana officinalis L.) improves sleep quality in man. Pharmacol Biochem Behav 17: 65-71

19. Mejlon HA, Jaenson TGT (1993) Seasonal prevalence of Borrelia burgdorferi in Ixodes ricinus in different vegetation types in Sweden. Scand J Infect Dis 25: 449-456

20. Yamaguti N, Tipton VJ, Keegan HI, Toshioka S (1971) Ticks of Japan, Korea and the Ryukyu Islands. Brigham Young Univ Sci Bull 15:1-226

21. Yang JY, Kim MG, Park JH, Hong ST, Lee HS (2014) Evaluation of benzaldehyde derivatives from Morinda officinalis as anti-mite agents with dual function as acaricide and mite indicator. Sci rep 4: 7149-7155

22. Wang J, Zhao J, Liu H, Zhou L, Liu Z, Wang J, Han J, Yu Z, Yang F (2010) Chemical Analysis and Biological Activity of the Essential Oils of Two Valerianaceous Species from China: Nardostachys chinensis and Valeriana officinalis. Molecules 15: 6411-6422

23. Pavlovic M, Kovacevic N, Tzakou O, Couladis M (2004) The Essential Oil of Valeriana officinalis L. s.l. Growing Wild in Western Serbia. J. Essent Oil Res 16: 397-399

24. Huang B, Qin L, Chu Q, Zhang Q, Gao L, Zheng H (2008) Comparison of Headspace SPME with Hydrodistillation and SFE for Analysis of the Volatile Components of the Roots of Valeriana officinalis var. latifolia. Chromatographia 69: 489-496

25. Maddonni GA, Urricariet S, Ghersa CM, Lavado RS (1999) Assessing soil quality in the Rolling Pampa, using soil properties and maize 
characteristics. Agron J 91: 280-287

26. Pavela R (2011) Screening of Eurasian plants for insecticidal and growth inhibition activity against Spodoptera littoralis larvae. Afr J Agric Res 6: 2895-2907

27. Dua VK, Alam MF, Pandey AC, Rai S, Chopra AK, Kaul VK, Dash AP (2008) Insecticidal activity of Valeriana jatamansi (Valerianaceae) against mosquitoes. J Am Mosq Control Assoc 24: 315-318

28. Jeong EY, Lee MJ, Kang MS, Lee HS (2018) Antimicrobial agents of 4methoxysalicylaldehyde isolated from Periploca sepium oil against foodborne bacteria: structure-activity relationship. Appl Biol Chem 61: $397-402$ 